5. Zhytnyk N.V. Orhanizatsiino-pedahohichni umovy pidhotovky bakalavriv ekonomiky v koledzhi II rivnia akredytatsii: dys... kand. ped. nauk. / Zhytnyk N.V. - Kryvyi Rih, 2001. - 223 s. [ukr].

6. Klymenko Yu.A. Profesiina mobilnist maibutnikh uchyteliv u krainakh Yevrosoiuzu: avtoref. dys. ... kand. ped. nauk : 13.00.04 / Yu. A. Klymenko; Uman. derzh. ped. un-t im. P. Tychyny. — Uman, 2011. - 20 s. [ukr].

7. Klymenko Yu. A. Pedahohichni umovy formuvannia profesiino mobilnoho pedahoha u yevropeiskykh vyshchykh navchalnykh zakladakh / Yu. A. Klymenko // Pedahohichni nauky : zb. nauk. prats.- Kherson: Vydavnytstvo KhDU, 2011. - Vyp. 58. - S. 74-79. [ukr].

8. Chorna I.I. Obhruntuvannia pedahohichnykh umov formuvannia mobilnosti maibutnikh ekonomistiv zasobamy inozemnoi movy u protsesi navchannia u vyshchomu navchalnomu zakladi / I. I. Chorna // Zbirnyk naukovykh prats [Khersonskoho derzhavnoho universytetu]. Pedahohichni nauky. - 2017. - Vyp. 79(1). - S. 199-203. [ukr].

Одержано статтю: 5.02.2019

Прийнято до друку: 19.03.2019

УДК $376-056.36(73)$

DOI: $10.15330 /$ esu. $15.152-160$

\section{Світлана Чупахіна,}

кандидат педагогічних наук, доцент, ДВНЗ “Прикарпатський національний університет імені Василя Стефаника" (м. Івано-Франківськ, Україна)

Svitlana Chupakhina,

Candidate of pedagogical sciences $(\mathrm{PhD})$, Associate Professor, Vasyl Stefanyk Precarpathian national university (Ivano-Frankivsk, Ukraine)

cvitlana2706@gmail.com

\title{
ВИКОРИСТАННЯ ІНФОРМАЦЙНИХ ТЕХНОЛОГІЙ В НАВЧАННІ ДІТЕЙ 3 ОСОБЛИВИМИ ОСВІТНІМИ ПОТРЕБАМИ: ДОСВІД США
}

\section{USAGE OF INFORMATIONAL TECHNOLOGIES IN TEACHING OF CHILDREN WITH SPECIAL EDUCATIONAL NEEDS: EXPERIENCE OF THE USA}

В статті проаналізовано досвід американських учителів щодо використання інформачійних технологій у роботі з дітьми з особливими освітніми потребами в умовах інклюзивного навчання. Важливо зауважсити, щзо запровадження в Украйні інклюзивного навчання та зміна системи освіти загалом співпали у часі з інтенсивним розвитком цифрових комунікачій. Відтак важливим завданиям сучасної иколи стас повнота використання можливостей інформаційних технологій, їх потенціалу в навчанні дітей з особливими освітніми потребами. Актуальності набуває саме вивчення та розумне застосувания досвіду американських педагогів, співзвучного загальносвітовим тенденціям оновлених підходів до освіти в Украйні.

Проаналізовано теоретико-методологічні основи, стан та тендениій використання інформачійних технологій в освіті учнів з особливими освітніми потребами в США задля успішного їх використання в умовах інклюзивного освітнього середовича України.

Доведено, ио використания потенчіалу інформачійних технологій, як засобу навчання, так $і$ способу оволодіння ними на належному рівні, стає найважливіших завдань підготовки сучасних фахівиів в галузі освіти.

Аргументовано, ио освітній прочес слід організовувати таким чином, иоб кожна дитина, чи з проблемами фізичного/психічного здоров'я чи з “типовим” розвитком, мала можливість самостійно виконувати завдання у зручному для ней темпі та могла демонструвати власні досягнення.

Узагальнено, що проблеми, які обмежують використання інформачійних технологій в освіті дітей з особливими освітніми потребами в США, здебільиого універсальні, тобто с спільними на иляху інформатизачії освіти в краӥні загалом, водночас вони схожі з перешкодами, які гальмують інформатизачію вітчизняної освіти. 
Відтак набувас актуальності саме підготовка вчителів иодо формування у них цифрової компетентності та застосування інформачійних технологій у роботі з дітьми особливими освітніми потребами; вирішения проблеми доступності якісного спечіального програмного забезпечення; врахування санітарно-гігієнічних вимог щодо роботи дитини з комп'ютером. Отож вивчення досвіду американських вчених та практиків мас незаперечну чінність для вітчизияної освіти, в якій інформачійні технології починають широко застосовуватись, особливо в невеликих містах та в сільській місиевості.

Ключові слова: інформачійні технології, інформатизачія освіти, інклюзивне освітне середовище, цифрові комунікачії, спечіальне програмне забезпечення, навчання дітей з особливими освітніми потребами.

In the article experience of the American teachers is analysed in relation to the use of information technologies in-process with children with the special educational necessities in the conditions of inclusive studies. As introduction in Ukraine of inclusive studies and change of the system of education on the whole clashed with intensive development of digital communications. Consequently the important task of modern school is become by plenitude of the use of possibilities of information technologies, their potential, in the studies of children with the special educational necessities. Actuality is acquired by a study and clever application of experience of the American teachers, consonant to the world tendencies of the renewed approaches education in Ukraine.

The theoretical and methodological foundations, the state and trends of the use of information technologies in the education of students with special educational needs in the USA for their successful use in the conditions of the inclusive educational environment of Ukraine are analyzed.

It is proved that the use of the potential of information technologies, both mean of studies and method of capture, by them on a due levels, becomes major tasks of preparation of modern specialists.

It is argued that the educational process should be organized in such a wav that every child, with problems of physical / mental health or with "typical" development, has had the opportunity to perform tasks at a pace convenient for him and could demonstrate his own achievements.

Generalized, that problems, which limit the use of information technologies in education of children with the special educational requirements in the USA, mostly universal, that is general on the way of informatization of education in a country on the whole, at the same time they are alike with obstacles which brake informatization of domestic education.

Consequently preparation of teachers acquires actuality exactly in relation to forming for them of digital competence and application of information technologies in-process with children by the special educational necessities; decision of problem of availability of the high-quality special software; an account of sanitary-hygenic requirements is in relation to work of child with a computer. So the study of the experience of American scholars and practitioners has an undeniable value for native education, in which information technology is beginning to be widely used, especially in small cities and in rural areas.

Key words: information technologies, informatization of education, inclusive educational environment, digital communications, special software, teaching of children with special educational needs.

Постановка проблеми. Характерною рисою сучасної української освіти, поряд з глобальною інформатизацією, є ї гуманізація, спрямованість на розвиток особистості й реалізація творчого потенціалу кожної людини.

Європейське спрямування освіти, науково-технічний прогрес, стрімкий розвиток та поширення інформаційних технологій спонукає до кардинального оновлення процесу навчання загалом. Змінюється сама концепція освіти, метою якої стає не лише передача учням певних знань, а й формування: важливих умінь самостійно при потребі знаходити інформацію, критичного мислення, аналітичних навичок, готовності та здатності до творчості тощо. В таких умовах виникає 
необхідність перегляду засобів навчання. Спектр застосування інформаційних технологій в освіті безперервно розширюється; вдосконалення технічних пристроїв й програмного забезпечення вимагає розробки нових методичних підходів щодо їхнього використання в навчальному процесі сучасної школи.

У США накопичено важливий досвід педагогічної роботи 3 дітьми з ООП, побудовано систему диференційованих освітніх програм, створено грунтовну теоретико-методичну базу. Потреби “виняткових дітей” в США стали ключовою темою низки законів про освіту, прийнятих в країні впродовж другої половині ХХ століття. Серед них, на нашу думку, слід виокремити Акт про освіту всіх дітей 3 особливими потребами (Education of All Handicapped Children Act, 1975) та закон "Не залишати дитину позаду" (No Child Left Behind, 2002) та ін [5]. Структурною одиницею означених законів $\epsilon$ положення про надання можливостей отримати кращу освіту всім дітям, незалежно від їх здібностей, стану здоров'я, національності, матеріального добробуту та інших чинників. Активними засобами забезпечення доступу до освітніх послуг та їх якості законодавці закріпили саме інформаційні технології.

IT як засоби навчання, впродовж років, широко використовуються в практиці навчання "виняткових дітей" в США. Встановлено, що вони допомагають частково, а інколи, спроможні компенсувати недоліки розвитку дітей з ООП, полегшують їх соціалізацію, що набуває особливої актуальності в умовах включення дітей означеної категорії в загальноосвітню школу.

Досвід американських учителів щодо використання IT у роботі 3 дітьми 3 ООП в умовах інклюзивного навчання має велику цінність для вітчизняної освіти в сучасних умовах. Запровадження в Україні інклюзивного навчання та зміна системи освіти загалом співпали у часі 3 інтенсивним розвитком цифрових комунікацій. Сучасна школа недостатньо повно використовує можливості інформаційних технологій, недооцінено їх потенціал i в навчанні дітей 3 особливими освітніми потребами. Відтак розумне усвідомлення досвіду американських педагогів, співзвучного загальносвітовим тенденціям оновлених підходів до освіти в Україні. Отож актуальним для започаткованого дослідження $€$ грунтовний аналіз змісту, форм та методів використання інформаційних технологій в освіті дітей з особливими освітніми потребами в США.

Актуальність дослідження і публікації. Об'єднання різних дітей в єдиному освітньому просторі вимагає заглибитися в його теоретичне підгрунтя. Дослідження американських учених та педагогів-практиків стверджують, що процес навчання учнів в інклюзивному класі побудовано на основі єдиних дидактичних підходів індивідуалізації та диференціації, що дозволяє задовольнити їх "особливі" потреби в освіті, і в означеному процесі інформаційні технології посідають чільне місце [4]. Однак прослідковуються й суттєві відмінності, до яких ми звернемося досліджуючи особливості використання IT в роботі 3 дітьми з ООП в школах США.

Задля виявлення ступеня вивченості теоретичних ідей та практичного досвіду застосування інформаційних технологій в освіті “виняткових дітей” в США проаналізуємо педагогічні дослідження вітчизняних та зарубіжних учених, й низку досліджень в галузі філософії, культурології та інформатики.

Проаналізувавши теоретико-методологічні основи навчання дітей з ООП в США можемо стверджувати, що в його основу покладено філософську концепцію конструктивізму, що передбачає особистісно орієнтоване навчання, в якому саме 
особистість учня як творця свого власного знання знаходиться в центрі педагогічного процесу [2]. Філософські принципи використання інформаційних технологій в освіті опираються на філософію техніки, це обгрунтування місця техніки та технічного прогресу в суспільному розвитку (йдеться про погляди Х. Сколімовського, Е. Тоффлера, М. Хайдеггера, К. Ясперса та ін). Важливе місце в дослідженні теоретико-методологічних основ процесу інформатизації освіти в США відведено дослідження в галузі кібернетики (Н. Вінер), шо містять опис базисних для такого процесу категорій (інформації, комунікації та ін.)

Узагальнення психолого-педагогічних основ навчання дітей з ООП в США підтверджують, що його основою стає теорія надкомпенсації А. Адлера і теорії компенсації психічних функцій Л. Виготського, які є теоретичним підгрунтям для використання інформаційних технологій в освіті дітей з ООП.

В умовах становлення інформатизації вітчизняної освіти особливий інтерес мають дослідження вчених щодо проблемам використання комп'ютерних навчальних технологій, а саме: М. Афанасьєва, С. Буртового, Ю. Бабанського, В. Беспалько, В. Дорошенко, М. Кітаєвої, І. Захарової, В. Мадзігона, Н. Обухова, Е. Полат, Л. Пономаренко та ін.

Історичний аспект становлення інформаційних технологій в освіті обгрунтовано у працях вітчизняних та американських вчених Дж. Кемені, Р. Левьен, Е. Молнар, Р. Тейлор та ін.

Застосування інформаційних технологій в освітньому просторі сучасної школи відображено у роботах зарубіжних педагогів: Ф. Беннетт, Д. Дуайєр, М. Ідінг, К. Йокам, Б. Клем, М. Кросбі, JI. Лобау, М. Полсон, Дж. Річардсон, Дж. Саутворст, Ч. Фішер, Б. Хамиль та ін.

Важливі аспекти застосування інформаційних технологій в освіті “виняткових дітей” в США представлені в дослідженнях таких вчених, як Дж. Вудроу, Д. Дюхейні, Л. Дюхейні, С. Пейперт, М. Спенсер, Л. Флоріан, Дж. Хегарті, В. Шарп та ін.

Грунтовний аналіз особливостей використання комунікаційних технологій в навчанні проводили А. Бейтс, І. Захарова, Д.Істмонд, Ф. Мюллер, Е. Полат, В. Філіпчак та ін.

Відтак можемо стверджувати, що проблема використання інформаційних технологій в освіті дітей $з$ ООП широко обговорюється у науковій теорії та практиці США, також $\epsilon$ актуальною в дослідження вітчизняних науковців.

Мета статті: проаналізувати теоретико-методологічні основи, стан та тенденції використання інформаційних технологій в освіті учнів з ООП в США задля успішного їх використання в умовах інклюзивного освітнього середовища України.

Виклад основного матеріалу. В сучасних умовах інформація стає важливим ресурсом науково-технічного та соціально-економічного розвитку людства, істотно впливаючи на прогрес науки, техніки, економіки та освіти у світі, а їі продукування $\epsilon$ основним видом діяльності людей. Відтак зростає потенціал інформаційних технологій, як засобів навчання, так і способів оволодіння ними на належному рівні, що стає найважливіших завдань підготовки сучасних фахівців.

Для започаткованого дослідження важливо розглянути такі поняття, як “інформаційні технологіi”, “інформатизація освіти” і “використання інформаційних технологій в освіті".

Отож під інформаційними технологіями будемо розуміти методи і способи накопичення, передачі, обробки та збереження інформації з допомогою технічних засобів, які змінюються й удосконалюються в процесі розвитку науки і техніки [3]. 
Основою IT є комп'ютерні засоби. В дослідженні під освітніми інформаційними технологіями розуміємо саме комп'ютерні технології навчання.

Інформатизація освіти - це масове впровадження в педагогічну практику інформаційних технологій, а також педагогічних технологій, які базуються на IT як засобах для перебудови пізнавальної діяльності та підсилення інтелектуальних можливостей учнів [7].

Використання інформаційних технологій в освіті - вужче поняття, $є$ одним 3 обов'язкових етапів загальноприйнятої інформатизації освіти 3 урахуванням можливостей інформаційних технологій та розробкою спеціального навчального програмного забезпечення [1].

Інформатизації американського шккільної освіти відбувається під впливом низки важливих умов, які виділяються ученими як загальні аспекти історичного розвитку означеного процесу в США (рис.1).

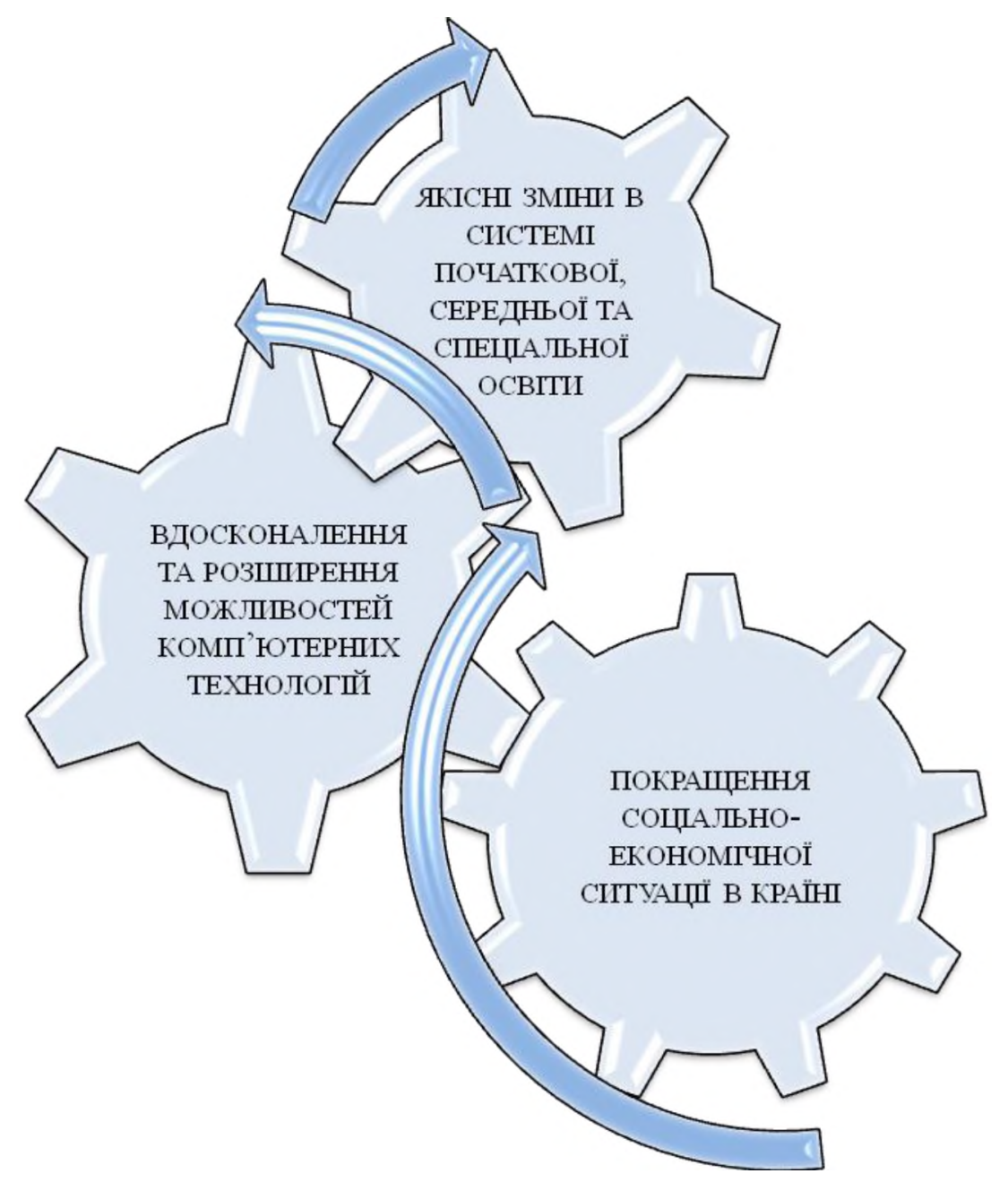

Рис.1. Передумови інформатизації американського шкільної освіти

Важливою умовою ефективності застосування інформаційних технологій в освіті $€$ їх гармонійне та науково обгрунтоване включення в комплекс традиційних засобів навчання, що забезпечується дотриманням певних принципів (рис. 2). 


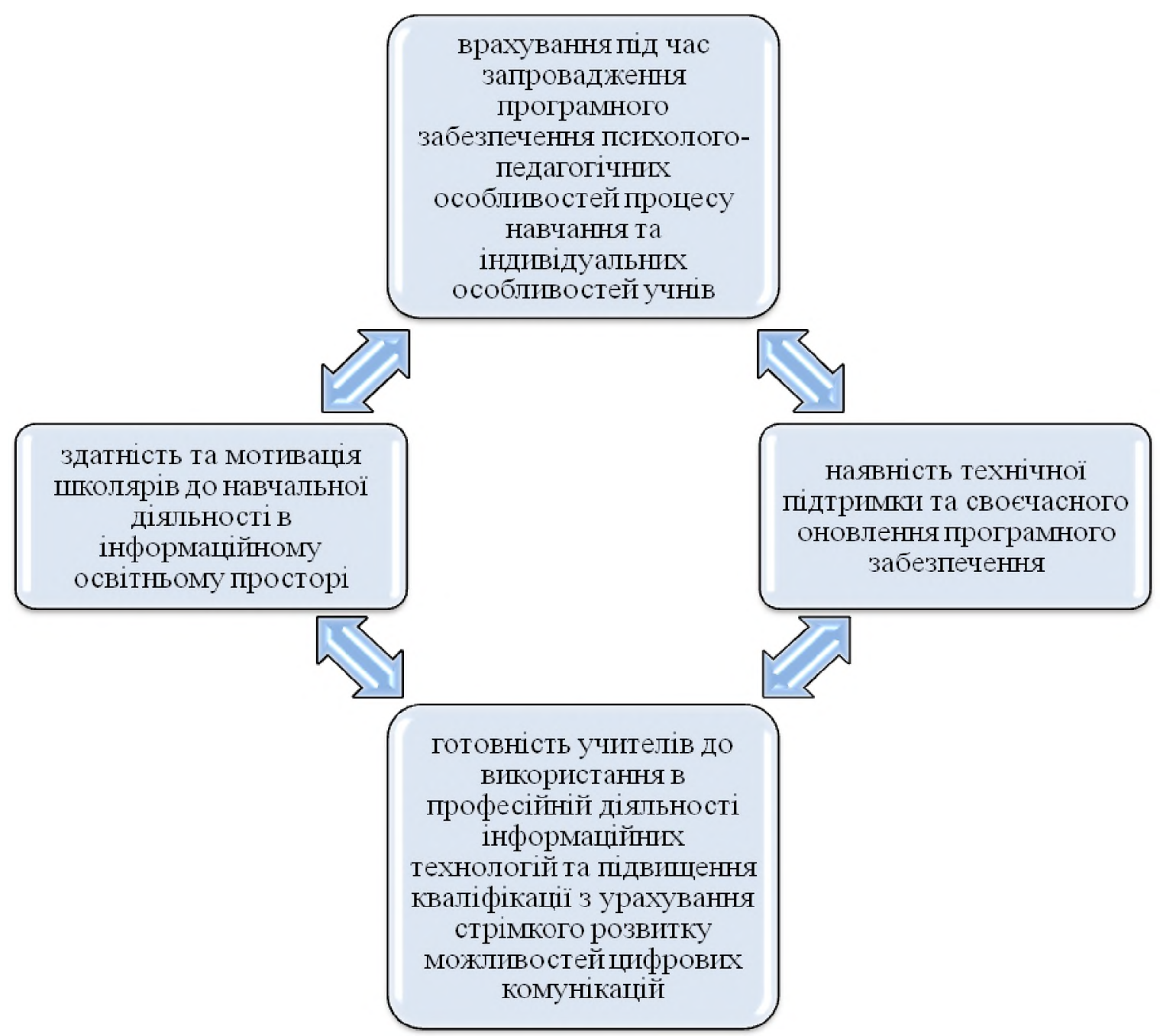

Рис. 2. Принципи ефективного застосування IT в освіті

Організація освіти дітей з особливими освітніми потребами в включає два основних типи шкіл: традиційні та спеціальні. Відтак це інтегроване навчання дітей з ООП в освітньому середовищі традиційної школи та навчання таких дітей в спеціальному освітню середовищі, тобто в умовах кімнати реабілітації, спеціального класу чи спеціальної школи.

Особливості застосування інформаційних технологій в освіті дітей з ООП побудовано на ідеях, так би мовити, компенсування порушень. Як засіб компенсування в США здебільшого використовуються допоміжні (адаптивні) технології, призначені для адаптації інформаційних технологій загального призначення до потреб і можливостей дітей з ООП та для полегшення їх соціалізації. Під допоміжними (адаптивними) технологіями (поняття взаємозамінні) розуміються певні прилади/системи, виготовлені промисловим способом, які модифіковано для підвищення/підтримки функціональних можливостей осіб з ООП [7].

Відтак у роботі 3 дітьми 3 порушеннями опорно-рухового апарату (OPA) застосовують телекомунікаційні технології, які дозволяють частково відшкодувати обмежену рухливість таких учнів. Інколи це дистанційне навчання, спілкування 3 допомогою електронної пошти, отримання інформації 3 Інтернету та подальше іiі використання в навчальному самоосвітньому процесі. Особливе значення серед 
форм роботи 3 використанням телекомунікаційних технологій мають віртуальні екскурсії, які збагачують процес навчання дітей.

Серед комп'ютерних технологій для учнів з вадами зору та з важкими порушеннями мовленнєвої діяльності слід назвати альтернативні системи розширення спілкування (augmentative and alternative communication, AAC) [4]. Це пристрої, що спроможні генерувати висловлювання, відтак дитина може бути активною в житті, спілкуватися з однолітками та вчителями під час навчання, вільно висловлювати власні думки [6].

У навчанні дітей 3 порушеннями слуху застосовуються технології для підсилення надходження звукового сигналу. Серед них відомі частотномодульовані системи посилення звуку, аудіоцикли, “Телекомунікаційні пристрій для нечуючих" (Telecommunication Device for the Deaf), субтитри. Означені технології використовуються на різних етапах навчального процесу та особливо актуальні вони в умовах включення дітей 3 порушеннями до загальноосвітніх закладів $[5,6]$.

Технології створені для дітей 3 порушеннями зору дозволяють їм користуватися ресурсами бібліотек, Інтернет-мережею, збільшувати зображення, здебільшого це спеціальні пристрої для сканування та озвучування тексту, демонстрування зображення на екрані зі словесним коментарем до нього [5].

Стосовно програмного забезпечення створеного роботи 3 дітьми 3 ментальними порушеннями, то, найбільш популярними $\epsilon$ адаптовані до їхніх можливостей та потреб технології для роботи з текстом (текстові редактори), які забезпечують розширення словникова дітей, сприяють підвищенню мотивації до навчання та роботи з текстом зокрема, полегшують виконання основних навчальних завдань $[7]$.

Аналіз досвіду впровадження інформаційних технологій в освіту “виняткових дітей” в США дозволив виявити позитивні сторони такого підходу до навчання і певні проблеми, які знижують результативність процесу інформатизації освіти в країні загалом (рис.3).

Вирішення означених проблем в США зосереджено на забезпеченні організації якісної підготовки майбутніх фахівців у $3 \mathrm{BH}$ та підвищенні їх кваліфікації; залучення приватного й державного капіталу для придбання сучасного комп'ютерного обладнання; дотримання правил та інструкцій щодо роботи 3 комп'ютером [7].

Проблеми, які обмежують використання IT в освіті дітей з ООП в США, здебільшого універсальні, тобто не є спільними на шляху інформатизації освіти в країні загалом, водночас вони схожі з перешкодами, які гальмують інформатизацію вітчизняної освіти.

Відтак набуває актуальності: підготовка вчителів щодо формування у них цифрової компетентності та застосування у роботі 3 дітьми $з$ ООП інформаційних технологій, однак на новому сучасному рівні; вирішення проблеми доступності якісного спеціального програмного забезпечення; врахування санітарно-гігієнічних вимог щодо роботи дитини 3 комп'ютером. Вивчення досвіду американських вчених та практиків має безперечну цінність для вітчизняної освіти, в якій інформаційні технології починають широко застосовуватись, особливо в невеликих містах та в сільській місцевості. 


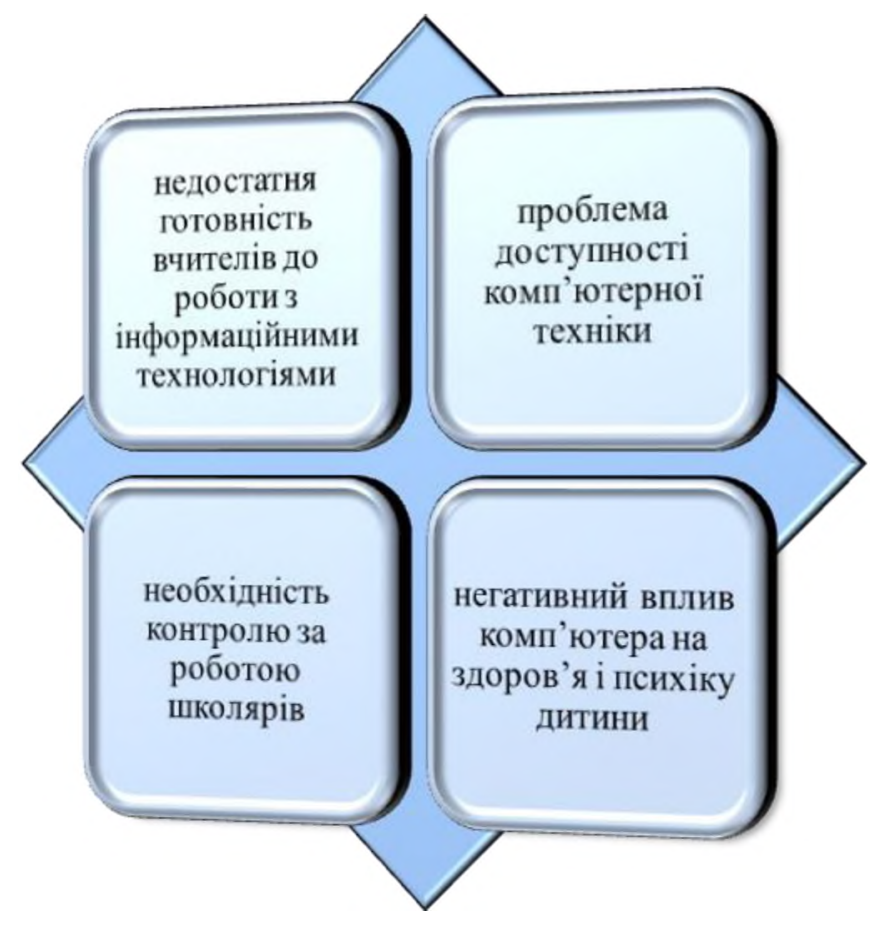

Рис. 3. Чинники, що впливають на результативність інформатизації освіти

Висновки. Стає зрозумілим, що важливим для українського освітнього простору є досвід США щодо вирішення порушеної проблеми. Зокрема, це зміна змісту вищої педагогічної освіти з підсиленням методичної підготовки педагогів до роботи в умовах інформації освіти та використання інформаційних технологій 3 особливими групами дітей. Забезпечення загального доступу до освітніх інформаційних технологій можливе при хорошій матеріально технічній базі що вимагає покращення технічної бази. Проблема охорони здоров'я школярів, запобігання негативного впливу комп'ютерів вирішується втановленням правил та інструкцій щодо роботи з ними, вивчення означених правил та інструкцій учнями та цілковите їх дотримання усіма учасниками освітнього процесу.

За межами дослідження залишилася низка важливих питань, які вимагають подальшого грунтованого аналізу. До таких, слід віднести аналіз особливостей використання інформаційних технологій у роботі 3 дітьми 3 поведінковими девіаціями, з тими, кого в США прийнято називати "підлітками групи ризику". Відтак можемо стверджувати, що навчальна робота корекційно-розвиткового спрямування із використанням інформаційних технологій, широкого обговорюється педагогічною громадськістю США та вимагає започаткування досліджень на рівні держави і в Україні.

Мало дослідженими $€$ питання про особливості використання інформаційних технологій в освіті дорослих з особливими освітніми потребами в США. Увагу до освіти молоді з ООП та залучення їх до участі в суспільному житті пояснюють існування дистанційних курсів для дорослих. Дослідження означеного аспекту роботи 3 людьми 3 інвалідністю має першорядне значення для української дійсності і відтак вимагає окремого розгляду. Література

1. Бондар В. І. Діти з особливими потребами в загальноосвітньому просторі : початкова ланка Посібник [для вчителів початкових класів] В. І. Бондаря, В. В. Засенка - К. : - $2004-152$ с. 
2. Захарчук М. Є. Аналіз системи підготовки педагогів інклюзивної школи у США [Електронний ресурс] / М. Є. Захарчук, Ю. В. Закаулова // Науковий вісник Мелітопольського державного педагогічного університету. Серія: Педагогіка. - Мелітополь, 2014. - № 1. - С. 21-28. - Режим доступу: http://nbuv.gov.ua/UJRN/Nvmdpu_2014_1 4

3. Олдей В., Аллан Р. Інклюзивна освіта в Сполучених Штатах Америки // Шккільна бібліотека. - 2009. - №4. - C. 94.

4. Duhaney L., Duhaney D. Assistive technology meeting the needs of learners with disabilities // International Journal of Instructional Media. - 2000. - Vol. 27.-Is. 4.-P. 393-403.

5. Harr J. The 1997 Reauthorization of the Individuals with Disabilities Education Act // Journal of disability policy studies. -2000 . - Vol. 11. - Is. 2. - P. 111-127.

6. Smith T. E. C. IDEA 2004: Another Round in the Reauthorization Process //Remedial and Special Education. -2005. - Vol. 26. - pp. 314-317.

7. US Department of Education // http://www.ed.gov/

\section{References}

1. Bondar V. I. Dity $\mathrm{z}$ osoblyvymy potrebamy $\mathrm{v}$ zahalnoosvitnomu prostori : pochatkova lanka Posibnyk [dlia vchyteliv pochatkovykh klasiv] V. I. Bondaria, V. V. Zasenka - K. : - 2004-152 s.

2. Zakharchuk M. Ye. Analiz systemy pidhotovky pedahohiv inkliuzyvnoi shkoly u SShA [Elektronnyi resurs] / M. Ye. Zakharchuk, Yu. V. Zakaulova // Naukovyi visnyk Melitopolskoho derzhavnoho pedahohichnoho universytetu. Seriia: Pedahohika. - Melitopol, 2014. - № 1. - S. 2128. - Rezhym dostupu: http://nbuv.gov.ua/UJRN/Nvmdpu_2014_1_4

3. Oldei V., Allan R. Inkliuzyvna osvita v Spoluchenykh Shtatakh Ameryky // Shkilna biblioteka. 2009. - №4. - C. 94.

4. Duhaney L., Duhaney D. Assistive technology meeting the needs of learners with disabilities // International Journal of Instructional Media. - 2000. - Vol. 27.-Is. 4.-P. 393-403.

5. Harr J. The 1997 Reauthorization of the Individuals with Disabilities Education Act // Journal of disability policy studies. - 2000. - Vol. 11. - Is. 2. - P. 111-127.

6. Smith T. E. C. IDEA 2004: Another Round in the Reauthorization Process //Remedial and Special Education. -2005. - Vol. 26. - pp. 314-317.

7. US Department of Education // http://www.ed.gov/

УДК 378.147:373.3.011.3-051

DOI: $10.15330 /$ esu. $15.160-169$
Зоя Шевців,

доктор педагогічних наук, професор, Рівненський державний гуманітарний Університет (м. Рівне, Україна)

Zoia Shevtsiv, Doctor of Pedagogical Sciences, Professor, Rivne State University Humanitarian University (Rivne, Ukraine) shevtsiv53@ukr.net

\section{ФОРМУВАННЯ ІНТЕГРАЛЬНОӤ СОЦІАЛЬНО-ПЕДАГОГІЧНОӤ КОМПЕТЕНТНОСТІ МАЙБУТНЬОГО ВЧИТЕЛЯ ПОЧАТКОВИХ КЛАСІВ ДО ІНКЛЮЗИВНОГО НАВЧАННЯ}

\section{FORMING OF THE INTEGRATED SOCIAL-PEDAGOGICAL COMPETENCE OF THE FUTURE TEACHER OF PRIMARY SCHOOL TO INCLUSIVE EDUCATION}

У статті представлено теоретичний аналіз інтегральної сочіально-педагогічної компетентності вчителя початкових класів закладу загальной середньої освіти до організації інклюзивного навчання. Схарактеризовано складники інтегрованої сочіальнопедагогічной компетентності. Обтрунтовано закономірності та притиипи формувания інтегральної сочіально-педагогічної компетентності у процесі професійної підготовки 6 закладі вицой освіти. Визначено етапи, мету, завдання, методи і форми формування у 